\title{
Türkiye'de Sınıf Öğretmenleri ile İlgili Yapılan Lisansüstü Tezlerin Cinsiyet Değişkeni Açısından Değerlendirilmesi
}

\author{
Nisa KARA \\ Milli Eğitim Bakanlığ1 \\ nisakara9334@gmail.com \\ Mehmet Kaan DEMIR \\ Çanakkale Onsekiz Mart Üniversitesi \\ mkdemir2000@yahoo.com
}

Gönderilme Tarihi: 19/05/2020

Kabul Tarihi: 25/11/2020

Yayınlanma Tarihi: 30/11/2020

DOI: $10.30855 /$ gjes.2020.06.03.003

\begin{tabular}{l}
\hline \hline Makale Bilgileri \\
\hline Anahtar Kelimeler: \\
Sınıf öğretmeni, \\
Cinsiyet, \\
Lisansüstü tez
\end{tabular}

\begin{abstract}
ÖZET
Bu araştırmada sınıf öğretmenleri ile ilgili yapılan lisansüstü tezlerde "kadın" ve "erkek" sınıf öğretmenleri arasında anlamlı fark yaratan durumların nicel olarak ortaya konulması amaçlanmıştır. Bu çalışma nicel paradigmanın benimsendiği, tarama modelinde hazırlanmış içerik analizi yönteminin kullanıldığı bir araştırmadır. Araştırmanın verilerini Yükseköğretim Kurulu'nun (YÖK) web sayfasından "Ulusal Tez Merkezi" aracılığıyla pdf formatında yayımlanma izni bulunan, 2000-2020 yılları arasında Türkiye'de sınıf öğretmenleri ile ilgili yapılan lisansüstü tezlerden, cinsiyet değişkenine göre anlamlı farkların bulunduğu çalışmalar oluşturmuştur. İncelemeye tabi tutulan tezlere, tez arama motorunda "sınıf öğretmeni" anahtar kelimeleri ile yapılan tarama sonucunda ulaşılmıştır. Araştırmada verilerin analizinde SPSS paket programından yararlanılmıştır. Araştırma sonuçlarına göre; sınıf öğretmenleri ile ilgili cinsiyet değişkenine bağlı olarak anlamlı farklılıkların bulunduğu tezlerin çoğunun yüksek lisans tezi olduğu tespit edilmiştir. Tez yazarlarının ve tez danışmanlarının çoğunun erkek olduğu ayrıca tez danışmanlarının çoğunluğunun Dr. Öğr. Üyesi olduğu görülmüştür. Tezlerde en çok nicel araştırma metodunun kullanıldığı ve en çok ölçme aracı olarak ölçek kullanıldığı saptanmıştır. Tezlerde bulunan değişkenler arasında cinsiyetin birinci sırada yer aldığı, araştırmaların en çok ilçe merkezlerinde yapıldığı bulgusuna ulaşılmıştır. Tezlerin örneklemini daha çok kadınların oluşturduğu tespit edilmiştir. Tezlerde cinsiyete bağlı olarak en çok bir adet anlamlı farkın bulunduğu ve tezlerde en çok kadınların lehine anlamlı farklılık yaratan durumların bulunduğu tespit edilmiştir. Tezlerde erkek sınıf öğretmenleri açısından en çok anlamlı fark yaratan durumun "Alan eğitimi dersleri öğretimine ilişkin yeterlik düzeylerinin yüksek olması" ve "Ö̆ğretimsel liderlik düzeylerinin yüksek olması" olduğu görülürken, kadınlar açısından en çok anlamlı fark yaratan durumun ise "Sınıf yönetimi becerilerinin yüksek olması" olduğu tespit edilmiştir.
\end{abstract}

Kara, N. \& Demir, M. K. (2020). Türkiye' de sınıf öğretmenleri ile ilgili yapılan lisansüstü tezlerin cinsiyet değişkeni açısından değerlendirilmesi. Gazi Eğitim Bilimleri Dergisi, 6(3), 300-316.

DOI: https://dx.doi.org/110.30855/gjes.2020.06.03.003

Dergi Web Sayfası: http://dergipark.gov.tr/gebd 


\section{The Evaluation of Graduate Theses Related to the Classroom Teachers in Turkey in Terms of Gender Variable}

\begin{tabular}{ll}
\hline \hline Article Info & ABSTRACT \\
\hline Keywords: & In this research, it is aimed to quantitatively reveal the situations that make a \\
Glassroom teacher, & significant difference between "female" and "male" classroom teachers in the \\
graduate theses about classroom teachers. The data acquired in this screening model- \\
Graduate thesis \\
pased study, is analyzed by the content analysis method and the quantitative \\
paradigm is adopted. The data of the research consisted of studies with significant \\
differences according to gender variable among the graduate theses written about \\
the classroom teachers in Turkey between the years 2000-2020 which are allowed to \\
be published in pdf format through the "Thesis Center" on the web page of Council \\
of Higher Education (YÖK). The theses subject to the examination were obtained \\
through a search made with the keywords "classroom teacher" in the thesis search \\
engine. SPSS package program was used in the analysis of the data. According to the \\
results of the research; it is the master's thesis of most of the theses in which there are \\
significant differences depending on the gender variable related to classroom \\
teachers, most of the thesis writers and thesis advisors are male, the majority of thesis \\
advisors are Asst. Prof., mostly, quantitative research method is used in the theses \\
and scale is used as the measurement tool, among the variables found in the theses, \\
gender appears to be the first, most of the researches are conducted in district centers, \\
the sample of theses is mostly women, there is mostly one significant difference in \\
theses depending on gender and in the theses, it was found that there are situations \\
that make a significant difference in favor of women. In the theses, it is determined \\
that the situation that makes the most significant difference among the male \\
classroom teachers is between the "high proficiency evaluations about teaching the \\
field education lessons" and "The high level of instructional leadership relations", \\
while the situation that makes the most significant difference among women".
\end{tabular}

\section{GİRIŞ}

Günümüzde üniversitelerin işlevleri, hızla değişen ve artan bilgi birikimi karşısında değişmek zorunda kalmıştır. İstenilen yüksek nitelikli insan gücü artık lisansüstü düzeyde eğitimle yetiştirilmeye başlanmıştır. Önceleri lisans mezunu olmak ayrıcalıklı sayılırken, şimdilerde yüksek lisans ya da doktora eğitimi bireye ayrıcalık sağlamaktadır (Güven ve Tunç; 2007; Kara, 2008). Üniversitelere öğretim elemanı yetiştirmenin dışında, endüstriyel alanlarda ve diğer çalışma alanlarında iş edinmenin bir ön koşulu olarak yüksek lisans ve doktora derecesinin de aranır hale gelmesi, lisansüstü eğitime olan ihtiyacı daha da artırmıştır (Karaman ve Bakırcı, 2010). Lisansüstü eğitim; lisans eğitimine dayalı olan yüksek lisans ve doktora eğitimi ile sanat dallarında yapılan sanatta yeterlik çalışması ve tıpta uzmanlık ile bunların gerektirdiği eğitim, öğretim, bilimsel araştırma ve uygulama etkinliklerinden oluşan eğitim olarak tanımlanır (Sevinç, 2001). Lisansüstü eğitimin araştırma, mesleki gelişim, öğretmeyi öğrenme ve bunlara bağlı mesleki kültür, akademik kültür ve etik konularını en üst sosyal, bilişsel ve işitsel düzeylerde edinme süreci olduğu söylenebilir (İnce ve Korkusuz, 2006). 
Lisansüstü eğitimin işlevleri, üniversitelerin işlevleri ile paralellik göstermektedir. Bilim ve sanat üretmek, yaymak, toplumsal sorunları doğru algılamak ve sorunlara çözüm önerileri geliştirmek ve üst düzey insan gücünün yetiştirilmesine katkıda bulunmak şeklinde belirtilebilecek bu işlevler doğrultusunda, lisansüstü eğitimin önemi günümüzde giderek artmaktadır (Arıc1, 2001). Lisansüstü eğitimin, yurt içi ve yurt dışı programlar olmak üzere iki kaynağı bulunmaktadır. Türkiye'de, 1929 tarihli 1416 sayılı yasa ve 1981 tarihli 2547 sayılı yasa çerçevesinde lisansüstü eğitim için yurt dışına öğrenci gönderilmektedir. Türkiye'de lisansüstü eğitim 1982 yılından itibaren Yükseköğretim Kurulu'na bağlı olarak yasada yer alan enstitüler aracıllğıyla yürütülmektedir. Lisansüstü eğitim, üniversiteler içinde örgütlenecek şekilde lisansüstü eğitimin organize edilmesi ve yürütülmesi amacı ile kurulan ve 2547 sayılı Yükseköğretim Kanunu ile yürürlüğe giren enstitülerce düzenlenmiş olup üslendikleri görevler, belirli çerçeve ve yönetmeliklerle belirlenmiştir (Karaman ve Bakırcı, 2010).

Üniversitelerdeki enstitüler yani eğitim bilimleri, sosyal bilimler, fen bilimleri ya da sağlık bilimleri gibi enstitüler 2018 yılında yapılan kanun değişikliğiyle tek çatı altında toplanıp Lisansüstü Eğitim Enstitüsü adını almıştır. Bakanlar Kurulu tarafından 09/04/2018 tarihinde kabul edilerek Türkiye Büyük Millet Meclisine (TBMM) sevk edilen "Yükseköğretim Kanunu ile Bazı Kanun ve Kanun Hükmünde Kararnamelerde Değişiklik Yapılmasına Dair Kanun Tasarısı" TBMM Milli Eğitim Komisyonunda kabul edilmesinin ardından 18.05.2018 tarihinde resmi gazetede yayımlanarak yürürlüğe girmiştir (Resmi Gazete, 2018). Bazı üniversitelerde sayıları ondan fazla olan enstitülere tek çatı altında toplanma imkanı yaratan bu kanunla yeni kurulan üniversitelerdeki enstitüler birleştirilmiştir. Bu yeni akademik yapılanmada tüm lisansüstü öğrenciler "Lisansüstü Eğitim Enstitüsü" mezunu olurken, kayıt yaptıracakları anabilim dallarına göre yüksek lisans veya doktora tezi hazırlayacaklardır. Üniversite içinde yeni bir üniversite gibi de bir görüntü ortaya çıkmakla birlikte daha kolay yönetilebilir olma ve standartları ortak kılma adına olumlu olabilecek bu durum, birbirinden farklı alanların aynı bünyede toplanmasının yönetimsel zorluk yaratacağı ve enstitü yönetim kurullarının çok iyi seçilmesinin gerekliliği de ortadadır.

YÖKTEZ arama motorundaki istatistiklere göre "öğretmen" ile ilgili 23.986, "sinıf öğretmeni" ile ilgili ise toplam 1687 adet tez yazıldığı görülmektedir (https://tez.yok.gov.tr/). Bu durum geçmişten günümüze Türkiye' de eğitim alanında da lisansüstü eğitime verilen önemi destekler niteliktedir. Türkiye' de özellikle "sınıf öğretmenliği" ya da "sınıf eğitimi" alanında son 20 yılda ciddi sayıda yüksek lisans ya da doktora tezi yapıldı̆̆ı görülmektedir. Önceleri sosyal bilimler enstitüsü bünyesinde yapılan bu çalışmalar sonraki yıllarda eğitim bilimleri enstitülerinin çoğalmasıyla bu kurumlarda yapılmaya başlanmıştır. Özellikle doktora programları da yıllardır faal durumda olan Gazi Üniversitesi, Marmara Üniversitesi, Anadolu 
Üniversitesi gibi kurumların sınıf eğitimi alanında yapılan lisansüstü çalışmalarda başı çektiği görülmektedir.

Literatürde olaylar arasındaki ilişkiyi farklı açılardan ele almayı amaçlayan pek çok tez ve araştırma makaleleri olduğu görülmektedir. Araştırmalardaki olay, olgu veya durumlar ise “değişken" kavramına karşılık gelmektedir (Karasar, 2005). Türkiye'de ve dünyada yapılan birçok eğitim araştırmalarında cinsiyet bir değişken -belki de araştırmalarda en sıklıkla kullanılan değişken- olarak ele alınmakta ve araştırma sonucunu belirleyen ya da ilişkisi olduğu düşünülen önemli bir etken olarak görülmektedir.

Ülkemiz sayısı 19 milyona yaklaşan öğrenci sayısı ve 1.1 milyonu aşan öğretmen niceliğiyle dünyanın sayılı ülkelerinden biridir. Araştırma konumuz olan cinsiyet açısından bakıldığında öğretmen kadrosunun kadın açısından çoğunlukta olduğu görülmektedir. Milli Eğitim Bakanlığının her yıl yayınladığı Milli Eğitim İstatistikleri (MEB, 2019) derinlemesine incelendiğinde ve çıkarımlar yapıldığında konumuz açısından dikkat çeken hususlar şunlardır. Buna göre, okul öncesi eğitim kurumlarında çalışan 93302 öğretmenin \%94,38' i (88062 kişi), ilkokullarda çalışan 300732 öğretmenin \%64,02' si (192537 kişi), ortaokullarda çalışan 354198 öğretmenin \%58,34’ ü (206666 kişi) ve liselerde çalışan 371234 öğretmenin \%50,77’ si (188480 kişi) kadındır. Bu açıdan bakıldığında toplamda 1119466 öğretmenin \%60,36' sının 675745 kadın öğretmen olduğu ortaya çıkmaktadır. Özel olarak ilkokullar incelendiğinde ülke ortalamasının $(\% 60,36)$ üzerinde kadın öğretmen varlığı $(\% 64,02)$ olan tek kademe olduğu dikkat çekmektedir. İlkokulların büyük çoğunluğunu oluşturan sınıf öğretmenleri için bu durum şaşırtıcı değildir.

Öğretmen niceliği bir ülke için önemli olmakla birlikte daha da önemli olan husus öğretmen niteliğidir. Hiçbir uygulama, kanun, yönetmelik, program, yöntem, teknik, yaklaşım ve stratejinin başarısı onun uygulayıcısı olan öğretmenin başarısından bağımsız olamaz. Öğretmen ne kadar iyiye bu huşuların da iyi sonuç verme ihtimali söz konusu olacaktır. Köseoğlu'nun (1994) da ifade ettiği gibi öğrencilerin nitelikleri öğretmenlerinin nitelikleriyle özdeştir. Öğretmenin niteliği eğitim sistemlerinin işleyişi ve başarıya ulaşmasında oldukça büyük rol oynamaktadır. Kavcar'a (1987) göre de bir eğitim sisteminin en önemli unsuru, öğretmendir. Eğitim sisteminin başarısı, temelde sistemi işletip uygulayacak olan öğretmenlerin ve diğer eğitim personelinin niteliklerine bağlıdır. Hiçbir eğitim modeli, o modeli işletecek personelin niteliğinin üzerinde hizmet üretemez. Bundan dolayı, bir okul, ancak içindeki öğretmenler kadar iyidir denilebilir.

Aydın, Şahin ve Topal'ın (2008) aktardığına göre öğretmen yetiştirme sistemleri içinde önemli bir yer tutan sınıf öğretmenlerinin yetiştirilmesi özel bir öneme sahiptir. Çünkü ilköğretimin ilk yılları, çocuğun yetişkin yaşamına hazırlanmasına temel oluşturmakta, bu dönemde kazanılan bilgi ve beceriler üst kademe öğretimde kazandırılacak bilgi ve beceriler için 
alt yapı niteliği taşımaktadır (Gürkan, 1993). Bu açıdan sınıf öğretmenlerinin üstün yeteneğe, üstün empati gücüne ve çok yönlü işini başarabilmek için etkili bir hizmet öncesi ve hizmet içi eğitim sürecinden geçirilmeleri gerekmektedir (Senemoğlu, 1992).

Son yıllarda yapılan çalışmalarda tez incelemeleri üzerine araştırmaların yoğunlukla yapıldığı dikkat çekmektedir. Bu araştırmalarda da amaçsal boyutta nitelik yerine niceliğin ön plana çıktığı görülmektedir. Bununla birlikte alanyazında sınıf öğretmenleri ile ilgili veya farklı branş öğretmenleri ile ilgili yapılmış olan lisansüstü tezlerin cinsiyet değişkeni açısından incelenmediği tespit edilmiştir. Bu boyutta araştırmanın sınıf öğretmenlerini kapsayan lisansüstü tezlerin cinsiyet değişkeni açısından anlamlı farklılık yaratan durumların ele alınması açısından bir ilk olduğu söylenebilir. Araştırmada varılan sonuçların ileriki dönemlerde konu ile bağlantılı çalışma yapacak araştırmacılara ışık tutacağı düşünülmektedir.

Araştırmada sınıf öğretmenleri ile ilgili yapılan lisansüstü tezlerde "kadın" ve "erkek" sınıf öğretmenleri arasında anlamlı fark yaratan durumların nicel olarak ortaya konulması amaçlanmıştır. Türkiye'de yapılan tezlerin aşağıda alt amaç olarak belirtilen değişkenlere göre niceliksel olarak durumu incelenmiştir:

Tezlerin üst verilerine göre;

- Anlamlı fark durumu

- Tezlerin türü

- Tezlerin yapıldı $\breve{g ̆}_{1}$ yıl

- Tez yazarlarının cinsiyeti

- Tez danışmanlarının cinsiyeti

- Tez danışmanlarının unvanı

Tezlerin içeriğine göre;

- Tezlerde kullanılan yöntem

- Tezlerde kullanılan veri toplama aracı

- Tezlerde değişkenler arasında cinsiyet değişkeninin yer aldığı sıra

- Araştırmaların yapıldığı yerleşim birimi

- Tezlerdeki örneklem sayısının cinsiyete göre dağılımı

- Tezlerde cinsiyet değişkeni açısından anlamlı fark bulunan durum sayısı

- Tezlerde cinsiyet lehine göre anlamlı fark yaratan durumlar 
- Kadın sınıf öğretmenleri için anlamlı fark yaratan durumlar

- Erkek sinıf öğretmenleri.

\section{YÖNTEM}

$\mathrm{Bu}$ çalışma tarama modelinde hazırlanmış içerik analizi yönteminin kullanıldığı bir araştırmadır. Tarama modeli "geçmişte ya da halen var olan durumu olduğu şekliyle betimlemeyi amaçlayan araştırma yaklaşımıdır"' (Karasar, 2005, s.77).

\section{Verilerin Toplanması}

Araştırmanın verilerini Yükseköğretim Kurulu'nun (YÖK) web sayfasından "Ulusal Tez Merkezi" aracılığıyla pdf formatında yayımlanma izni bulunan, 18.05.2020 tarihinde 2000-2020 yılları arasında Türkiye'de sınıf öğretmenleri ile ilgili yapılan lisansüstü tezlerden, cinsiyet değişkenine göre anlamlı farkların bulunduğu çalışmalar oluşturmuştur. İncelemeye tabi tutulan tezlere, tez arama motorunda "sınıf öğretmeni" anahtar kelimeleri ile yapılan tarama sonucunda ulaşılmıştır. Belirlenen kriterlere göre yapılan bu taramada toplam 466 adet teze erişilmiştir. Nitel araştırma yöntemleriyle yapılan tezler çıkarılmış, sadece parametrik ve parametrik olmayan testlerle istatistiksel analiz yapılmış olan nicel ve karma yöntem tezleri dahil edilmiştir. Bu bağlamda toplam 141 adet tez araştırma verilerini oluşturmuştur.

\section{Verilerin Analizi}

Araştırma sonunda elde edilen verilerin istatistiksel analizinde SPSS paket programından yararlanılmıştır. Betimsel istatistik olarak yüzde ve frekans değerleri sunulmuştur. İncelenen tüm tezler alt problemlere göre tablolaştırılmış, daha sonra bu veriler yorumlanıştır.

\section{BULGULAR}

Araştırmada ele alınan alt problem sırasına göre bulgular 2 başlık altında elde edilmiş ve tablolar halinde sırayla verilmiştir.

\section{Tezlerin üstverilerine ilişkin bulgular}

Tablo 1.

Sınıf Öğretmenleri ile İlgili Tezlerin Cinsiyet Açısından Anlaml Fark Bulunma Durumlarına Göre Dağılımı

\begin{tabular}{lcc}
\hline Tezler & f & \% \\
\hline Anlamlı fark bulunmayan & 325 & 69,7 \\
Anlamlı fark bulunan & 141 & 30,2 \\
\hline Toplam & 466 & $\mathbf{1 0 0}$ \\
\hline
\end{tabular}

Tablo 1 incelendiğinde, 2000-2020 yılları arasında sınıf öğretmenleri ile ilgili yazılan ve erişime açık olan 466 tezin 325'inde cinsiyet değişkeni açısından anlamlı fark bulunmadığı, 141 
tezde ise anlamlı farkların olduğu görülmektedir. Bu bağlamda araştırma verilerini oluşturan tezlerin de 141 adet olduğu tablo 1'den anlaşılmaktadır. Bununla birlikte tablodan çıkartılması gereken bir diğer husus sınıf öğretmenleri ile ilgili yapılan tezlerin $466^{\prime}$ sin da cinsiyet değişkeninin yer aldığı gerçeğidir.

Tablo 2.

Tezlerin Türüne Göre Dağıllım

\begin{tabular}{lcc}
\hline Yükseköğrenim Derecesi & f & \% \\
\hline Yüksek lisans & 129 & 91,4 \\
Doktora & 12 & 8,5 \\
\hline Toplam & $\mathbf{1 4 1}$ & $\mathbf{1 0 0}$ \\
\hline
\end{tabular}

Tablo 2' de araştırmaya tabii tutulan 141 tezin $\% 91,4^{\prime}$ ünün yüksek lisans tezi, \%8,5'inin ise doktora tezi olduğu belirlenmiştir. Bu sonuca göre çoğunlukla yüksek lisans tezlerinde sınıf öğretmenleri arasında cinsiyet değişkeni açısından anlamlı farkların bulunduğu söylenebilir. Aynı zamanda yüksek lisans öğrenci sayısının doktora öğrencilerine oranla fazla olması da bu sonucu ortaya çıkaran etkenler arasında yer almaktadır. Ülkemizde bu alanda yani sınıf eğitimi doktora programı bulunan enstitüler günümüzde artmaya başlamıştır.

Tablo 3.

Tezlerin Yıllara Göre Dağılımlar

\begin{tabular}{lcc}
\hline Y1l & f & $\%$ \\
\hline 2003 & 1 & 0,7 \\
2005 & 2 & 1,4 \\
2006 & 5 & 3,5 \\
2007 & 11 & 7,8 \\
2008 & 10 & 7,0 \\
2009 & 12 & 8,5 \\
2010 & 7 & 4,9 \\
2011 & 8 & 5,6 \\
2012 & 5 & 3,5 \\
2013 & 10 & 7,0 \\
2014 & 9 & 6,3 \\
2015 & 13 & 9,2 \\
2016 & 3 & 2,1 \\
2017 & 4 & 2,8 \\
2018 & 11 & 7,8 \\
2019 & 26 & 18,4 \\
2020 & 5 & 3,5 \\
\hline Toplam & $\mathbf{1 4 1}$ & $\mathbf{1 0 0}$ \\
\hline
\end{tabular}


Tablo 3'e göre sını öğretmenleri ile ilgili yapılan ve cinsiyet değişkeni açısından anlamlı farklılıkların bulunduğu lisansüstü tezlerin en çok 2019 (\%18,4) yılında yazıldığı görülmektedir. 2019 yılında yazılan tezlerin 25'i yüksek lisans tezi 1'i ise doktora tezidir. Bunu takip eden yıllar ise sırasiyla 10' u yüksek lisans tezi 2' si doktora tezi olan $2009(\% 8,5)$ ve tümünün yüksek lisans tezi olduğu $2007(\% 7,8)$ ve $2018(\% 7,8)$ y1lları olmuştur.

Tablo 4.

Yazarların Cinsiyete Göre Dağılımları

\begin{tabular}{lcc}
\hline Cinsiyet & f & $\%$ \\
\hline Erkek & 77 & 54,6 \\
Kadın & 64 & 45,3 \\
\hline Toplam & $\mathbf{1 4 1}$ & $\mathbf{1 0 0}$ \\
\hline
\end{tabular}

Tablo 4'e bakıldığında incelenen tezlerin yazarlarının $77^{\prime}$ sinin erkek, $64^{\prime}$ ünün ise kadın olduğu sonucuna ulaşılmıştır. Bu bağlamda \%54,6 oranı ile erkek yazarların bu boyutta daha çok oldukları görülmektedir. Ülkemizdeki kadın öğretmen sayısının daha fazla (MEB, 2019) olduğu düşünüldüğünde bu konuyu çalışma konusundaki farklılık dikkat çekmektedir.

Tablo 5.

Danışmanların Cinsiyete Göre Dağılımları

\begin{tabular}{lcc}
\hline Cinsiyet & f & $\%$ \\
\hline Erkek & 93 & 65,9 \\
Kadın & 48 & 34,0 \\
\hline Toplam & $\mathbf{1 4 1}$ & $\mathbf{1 0 0}$ \\
\hline
\end{tabular}

Tablo 5'te ise danışman öğretim elemanlarının cinsiyete göre dağılımlarına yer verilmiştir. Buna göre danışman öğretim elemanlarının 93'ü erkek, 48'i ise kadındır. \%65,9 oran ile bu boyutta da cinsiyete göre erkeklerin üstünlük sağladığı anlaşılmaktadır. Yükseköğretim Kurulu verilerine (akt. AA, 2019) göre, Türkiye'deki 166.225 akademisyenin \%44,75' i (74391) kadınlardan oluşmaktadır. Bu açıdan bakıldığında akademideki erkek öğretim elemanı çoğunluğuna uygun bir durum olduğu ifade edilebilir.

Tablo 6.

Danışmanların Unvanlarına Göre Dağılımlan

\begin{tabular}{lcc}
\hline Unvan & f & \% \\
\hline Prof.Dr. & 40 & 28,3 \\
Doç. Dr. & 40 & 28,3 \\
Dr. Öğr. Üyesi & 58 & 41,1 \\
Dr. & 3 & 2,1 \\
\hline Toplam & $\mathbf{1 4 1}$ & $\mathbf{1 0 0}$ \\
\hline
\end{tabular}


Tablo 6 incelendiğinde; incelenen tezlerin danışman unvanlarına göre sırasıyla Dr. Öğr. Üyesi (\%41,1), Prof. Dr. (\%28,3), Doç. Dr. (\%28,3) ve Dr. $(\% 2,1)$ şeklinde yer aldığ1 görülmektedir. $\mathrm{Bu}$ bağlamda araştırma verilerinde danışman unvanlarının en çok Dr. Öğr. Üyesi olduğu sonucuna ulaşılmıştır. Aynı zamanda Dr. Öğr. Üyesi unvanına sahip 58 danışmanın 35'inin de erkek olduğu dikkat çekmektedir. Yükseköğretim Kurulu verilerine (akt. AA, 2019) göre, Türkiye'deki 166.225 akademisyenin 26 bin 453'ü profesör (\%15,91), 15 bin 451'i doçent (\%9,29), 39 bin 464'ü doktor öğretim üyesi (\%23,74), 36 bin 461'i öğretim görevlisi (\%21,93), 48 bin 396's1 araştırma görevlisi $(\% 29,11)$ olarak çalışmaktadır. Bu açıdan bakıldığında akademideki doktor öğretim üyesi olan öğretim elemanı çoğunluğuna uygun bir durum olduğu ifade edilebilir.

\section{Tezlerin içeriğine ilişkin bulgular}

Tablo 7.

Tezlerde Kullanilan Yönteme Göre Dağıllım

\begin{tabular}{lcc}
\hline Yöntem & $\mathbf{f}$ & $\%$ \\
\hline Nicel & 120 & 85,1 \\
Karma & 17 & 12,0 \\
Betimsel & 4 & 1,8 \\
\hline Toplam & $\mathbf{1 4 1}$ & $\mathbf{1 0 0}$
\end{tabular}

Tablo 7'de araştırmalarda kullanılan yöntemlerin nicel, karma ve betimsel araştırma yöntemleri olmak üzere 3 temaya ayrıldığı görülmektedir. Araştırmacıların en sık kullandığ yöntem ise nicel araştırma yöntemi $(\% 85,1)$ olmuştur. Bu araştırma yöntemini kullanım sıklığına göre karma yöntem $(\% 12,0)$ ve betimsel yöntem $(\% 1,8)$ takip etmektedir.

Tablo 8.

Tezlerde Kullanılan Veri Toplama Aracına Göre Dă̆ıllım

\begin{tabular}{lcc}
\hline Veri Toplama Aracı & f & \% \\
\hline Ölçek & 97 & 68,7 \\
Anket & 26 & 18,4 \\
Ölçek+ görüşme formu & 17 & 12,0 \\
Başarı testi & 1 & 0,7 \\
\hline Toplam & $\mathbf{1 4 1}$ & $\mathbf{1 0 0}$ \\
\hline
\end{tabular}

Tablo 8'de incelenen tezlerde araştırmacıların veri toplama aracı olarak ölçek, anket, ölçek+görüşme formu ve başarı testini tercih ettikleri görülmektedir. En sık tercih edilen veri toplama aracı ise ölçek $(\% 68,7)$ olmuştur. Kullanım sıklığına göre anket $(\% 18,4)$ ikinci sırada yer alırken, karma metot kullanılarak yapılan tezlerde ölçek+görüşme formu $(\% 12,0)$ üçüncü sırada, son sırada ise $\% 0,7$ oran ile başarı testinin yer aldığı tespit edilmiştir. İncelemeye tabi tutulan 
tezlerin büyük bir çoğunluğunda nicel araştırma metodunun kullanılmış olması da bu bulguyu destekler niteliktedir.

Tablo 9.

Tezlerde Bulunan Değişkenler Arasında Cinsiyetin Yer Aldı̆̆̆ Sıraya Göre Dağılım

\begin{tabular}{lcc}
\hline Sira & f & $\%$ \\
\hline 1 & 131 & 92,9 \\
2 & 8 & 5,6 \\
3 & 2 & 1,5 \\
\hline Toplam & $\mathbf{1 4 1}$ & $\mathbf{1 0 0}$ \\
\hline
\end{tabular}

Tablo 9'da sınıf öğretmenleri ile ilgili yapılan lisansüstü tezlerde cinsiyetin değişkenler arasında yer aldığı sıranın; 1, 2 ve 3 şeklinde temalara ayrıldığı görülmektedir. İncelenen tezlerde cinsiyetin en çok 1 . sırada $(\% 92,9)$ yer aldığı tespit edilmiştir. Bunu sırasıyla ikinci sıra $(\% 5,6)$ ve üçüncü sıra $(\% 1,5)$ takip etmektedir. Bu sonuçtan yola çıkılarak araştırmalarda cinsiyetin en önemli değişken olarak görüldüğü söylenebilir.

Tablo 10.

Araştırmaların Yapıldığı Yerleşim Birimine Göre Dağılım

\begin{tabular}{lcc}
\hline Yerleşim Birimi & f & \% \\
\hline İlçe merkez & 73 & 51,7 \\
İl merkez & 62 & 43,9 \\
İl-ilçe ve köy & 4 & 2,8 \\
Köy & 2 & 1,4 \\
\hline Toplam & $\mathbf{1 4 1}$ & $\mathbf{1 0 0}$
\end{tabular}

Tablo $10^{\prime}$ da incelenen tezlerde uygulamaların yapıldığı yerleşim birimlerine göre; ilçe merkez, il merkez, il-ilçe ve köy, köy olmak üzere 4 temaya ayrıldığı görülmektedir. Bu boyutta araştırmacıların en çok ilçe merkezlerinde $(\% 51,7)$ uygulama yaptıkları tespit edilmiştir. Bunu sırasıyla; il merkezi $(\% 43,9)$, il-ilçe ve köy $(\% 2,8)$ ve köy $(\% 1,4)$ takip etmektedir. Bu durum araştırmacıların daha çok görev yaptıkları ya da yaşadıkları yerlerin ilçeler olması ve buralarda araştırmalarını gerçekleştirmelerinden kaynaklanıyor olabilir.

Tablo 11.

Örneklem Sayısının Cinsiyete Göre Dağılımı

\begin{tabular}{lcc}
\hline Örneklem & f & $\%$ \\
\hline Kadın & 93 & 65,9 \\
Erkek & 47 & 33,3 \\
Eşit & 1 & 0,7 \\
\hline Toplam & $\mathbf{1 4 1}$ & $\mathbf{1 0 0}$ \\
\hline
\end{tabular}


Araştırmanın alt amaçlarından biri de örneklem sayısının cinsiyete göre dağılımı olmuştur. Bu bağlamda Tablo 11'de incelenen tezlerin örneklemlerini en çok kadınların $(\% 65,9)$ oluşturduğu görülmektedir. Bu boyutta erkekler $(\% 33,3)$ oranına sahip olurken, incelenen tezlerden yalnızca birinde kadın ve erkek sayısının eşit $(\% 0,7)$ olduğu gözlenmiştir. Örneklemin çoğunluğunu kadın öğretmenlerin oluşturmuş olması, daha çok kadınların öğretmenlik mesleğini tercih etmeleri ile ilişkilendirilebilir.

\section{Tablo 12.}

Tezlerin Anlamlı Fark Bulunan Durum Sayısına Göre Dağılımı

\begin{tabular}{lcc}
\hline Durum sayis1 & $\mathbf{f}$ & $\%$ \\
\hline 1 & 126 & 89,3 \\
2 & 9 & 6,3 \\
3 & 4 & 2,8 \\
4 & 2 & 1,4 \\
\hline Toplam & $\mathbf{1 4 1}$ & $\mathbf{1 0 0}$ \\
\hline
\end{tabular}

Tablo 12' de incelenen tezlerin anlamlı fark bulunan durum sayısına göre 1, 2, 3 ve 4 şeklinde temalara ayrıldığı görülmektedir. Tezlerde anlamlı fark bulunan durum sayısı en çok 1 $(\% 89,3)$ olmuştur. Yani genellikle tezlerde cinsiyet değişkenin 1 durumda anlamlı fark oluşturduğu görülmektedir. Bunu anlamlı farkın bulunduğu 2 durum $(\% 6,3), 3$ durum $(\% 2,8)$ ve 4 durum $(\% 1,4)$ takip etmektedir.

Tablo 13.

Tezlerde Anlamlı Fark Yaratan Durumların Cinsiyetlerin Lehine Göre Dağılımı

\begin{tabular}{lcc}
\hline Cinsiyet & $\mathbf{f}$ & $\%$ \\
\hline Kadın & 94 & 61,4 \\
Erkek & 59 & 38,5 \\
\hline Toplam & $\mathbf{1 5 3}$ & $\mathbf{1 0 0}$ \\
\hline
\end{tabular}

Tablo 13'te incelenen tezlerde anlamlı fark yaratan durumların cinsiyetlerin lehine göre dağılımları görülmektedir. Bu durumda en çok kadınların $(\% 61,4)$ lehine anlamlı farklılıkların olduğu tespit edilmiştir. Bu bulgunun paralelinde hangi durumların kadın sınıf öğretmenleri lehine hangi durumların erkek sınıf öğretmenleri lehine oluştuğu da incelenmiştir. 
Tablo 14.

Kadın Öğretmenler Açısından Anlamı Fark Yaratan Durumlar

\begin{tabular}{|c|c|c|}
\hline Durum & $\mathrm{f}$ & $\%$ \\
\hline $\begin{array}{l}\text { Sinıf yönetimi becerilerinin } \\
\text { yüksek olması }\end{array}$ & 8 & 8,5 \\
\hline $\begin{array}{l}\text { Üst düzey bilimsel süreç } \\
\text { becerilerine ilişkin tutumlarının } \\
\text { yüksek olması }\end{array}$ & 7 & 7,4 \\
\hline $\begin{array}{l}\text { Özyeterlik algılarının yüksek } \\
\text { olması }\end{array}$ & 5 & 5,3 \\
\hline $\begin{array}{l}\text { Empatik eğilimlerinin yüksek } \\
\text { olması }\end{array}$ & 5 & 5,3 \\
\hline $\begin{array}{l}\text { Derslerde yaratıcı etkinlik } \\
\text { uygulama düzeylerinin yüksek } \\
\text { olması }\end{array}$ & 5 & 5,3 \\
\hline $\begin{array}{l}\text { Öğretim programlarına ilişsin } \\
\text { görüşlerinin olumlu olması }\end{array}$ & 4 & 4,2 \\
\hline $\begin{array}{l}\text { Ögretim programı yeterlik } \\
\text { düzeyinin yüksek olması }\end{array}$ & 3 & 3,1 \\
\hline $\begin{array}{l}\text { Alternatif ölçme değerlendirme } \\
\text { yeterliklerinin yüksek olması }\end{array}$ & 3 & 3,1 \\
\hline $\begin{array}{l}\text { Okul yöneticilerine iliskin } \\
\text { memnuniyet düzeylerinin yüksek } \\
\text { olması }\end{array}$ & 3 & 3,1 \\
\hline $\begin{array}{l}\text { Mesleki doyumlarının yüksek } \\
\text { olması }\end{array}$ & 3 & 3,1 \\
\hline $\begin{array}{l}\text { Tükenmişlik düzeylerinin düşük } \\
\text { olması }\end{array}$ & 3 & 3,1 \\
\hline $\begin{array}{l}\text { Sosyal medyaya olan ilgilerinin } \\
\text { yüksek olması }\end{array}$ & 2 & 2,7 \\
\hline $\begin{array}{l}\text { Mesleki memnuniyetlerinin } \\
\text { yüksek olması }\end{array}$ & 2 & 2,1 \\
\hline $\begin{array}{l}\text { Veli ile iletişim düzeylerinin } \\
\text { yüksek olması }\end{array}$ & 2 & 2,1 \\
\hline Diğer & 37 & 39,3 \\
\hline Toplam & 94 & 100 \\
\hline
\end{tabular}

Tablo 14 incelediğinde birçok açıdan cinsiyet değişkeninin sınıf öğretmenleri açısından ele alındığı ve tezlerde kadınlar açısından en çok anlamlı fark yaratan durumun "Sınıf yönetimi becerilerinin yüksek olması" $(\% 8,5)$ olduğu görülmektedir. Bunu sırasıyla "Üst düzey bilimsel süreç becerilerine ilişkin tutumlarının yüksek olması " (\%7,4), " “Öz yeterlik algılarının yüksek olması" (\%5,3), “Empatik eğilimlerinin yüksek olması (\%5,3), " Derslerde yaratıcı etkinlik uygulama düzeylerinin yüksek olması" (\%5,3), "Öğretim programlarına ilişkin görüşlerinin olumlu olması" (\%4,2), " Öğretim programı yeterlik düzeyinin yüksek olması" (\%3,1), " Alternatif ölçme değerlendirme yeterliklerinin yüksek olması" (\%3,1), " Okul yöneticilerine ilişkin memnuniyet düzeylerinin yüksek olması" (\%3,1), "Mesleki doyumlarının yüksek olması" $(\% 3,1)$, " Tükenmişlik düzeylerinin düşük olması" $(\% 3,1)$, , Sosyal medyaya olan ilgilerinin yüksek olması" (\%2,7), " Mesleki memnuniyetlerinin yüksek olması" (\%2,1) ve "Veli ile iletişim düzeylerinin yüksek olması" $(\% 2,1)$ takip etmektedir. 
Tablo 14'de "Diğer" $(39,3)$ teması altında kadın sınıf öğretmenleri açısından anlamlı farklılık yaratan durumlar ise; "Depresyon düzeylerinin yüksek olması", "Atama ve yer değiştirmeye ilişkin sorun yaşamaları", "Öğrenci ile etkileşim düzeylerinin yüksek olması", "Öğrenen örgüt kültürüne ilişkin alg1 düzeylerinin yüksek olması", "Stresle baş etme düzeylerinin yüksek olması", "Kuruma bağlllık düzeylerinin yüksek olması", "Teknolojiye ilişkin olumsuz tutum içinde olma", "Tükenmişlik düzeylerinin yüksek olması", "Öğretim materyali kullanma düzeylerinin yüksek olması", "Sosyal yıldırmalara maruz kalma düzeylerinin yüksek olması", "Lisans programına ilişkin görüşlerinin olumsuz olması", "Matematik tutum puanlarının yüksek olması", "Matematik kaygı düzeylerinin yüksek olması", "İşkolik olma”, "Sınıf içi görev verme düzeylerinin yüksek olması”, “Öğrenciyi taktir etme düzeylerinin yüksek olması, "Performans görev puanlarının yüksek olması" ve "Yaşam boyu öğrenme eğilimlerinin yüksek olması", "Değerler eğitimine ilişkin araç-gereç kullanımının yüksek olması", "Okuma alışkanlıklarının yüksek olması", "Sınıflarında bulunan mülteci öğrenciler ile az sorun yaşanması", "Mesleki değerlerinin yüksek olması" , "Zaman yönetimi düzeylerinin yüksek olması", "İletişim beceri düzeylerinin yüksek olması", "Kültürel sermaye yeterlik düzeylerinin yüksek olması", "Yaşam boyu öğrenme eğilimlerinin yüksek olması" şeklinde sıralanmıştır.

Tablo 15.

Erkek Öğretmenler Açısından Anlamlı Fark Yaratan Durumlar

\begin{tabular}{|c|c|c|}
\hline Durum & $\mathbf{f}$ & $\%$ \\
\hline $\begin{array}{l}\text { Alan eğitimi dersleri öğretimine } \\
\text { iliškin yeterlik düzeylerinin } \\
\text { yüksek olması }\end{array}$ & 7 & 12,0 \\
\hline $\begin{array}{l}\text { Öğretimsel liderlik düzeylerinin } \\
\text { yüksek olması }\end{array}$ & 7 & 12,0 \\
\hline $\begin{array}{l}\text { İş doyum düzeylerinin yüksek } \\
\text { olması }\end{array}$ & 5 & 8,6 \\
\hline $\begin{array}{l}\text { Bilişim teknolojisi kullanma } \\
\text { düzeylerinin yüksek olması }\end{array}$ & 4 & 6,8 \\
\hline $\begin{array}{l}\text { Kendilerini daha yapılandırmacı } \\
\text { görmeleri }\end{array}$ & 3 & 5,1 \\
\hline $\begin{array}{l}\text { TPAB öz yeterlik algılarının } \\
\text { yüksek olması }\end{array}$ & 3 & 5,1 \\
\hline $\begin{array}{l}\text { Okul müdürlerinin iletişim } \\
\text { becerisine ilişkin görüşlerinin } \\
\text { olumlu yönde olması }\end{array}$ & 2 & 3,4 \\
\hline $\begin{array}{l}\text { Derste öğretim tekniklerini } \\
\text { kullanma düzeylerinin yüksek } \\
\text { olması }\end{array}$ & 2 & 3,4 \\
\hline $\begin{array}{l}\text { Örgütsel adalet algı düzeylerinin } \\
\text { yüksek olması }\end{array}$ & 2 & 3,4 \\
\hline Diğer & 24 & 39,6 \\
\hline Toplam & 59 & 100 \\
\hline
\end{tabular}


Tablo 15'e bakıldığında, tezlerde erkek sınıf öğretmenleri açısından en çok anlamlı fark yaratan durumun "Alan eğitimi dersleri öğretimine ilişkin yeterlik düzeylerinin yüksek olması" $(\% 12,0)$ ve "Öğretimsel liderlik düzeylerinin yüksek olması" $(\% 12,0)$ olduğu görülmektedir. Bunu sırasıyla; " İş doyum düzeylerinin yüksek olması" (\%8,6), “Bilişim teknolojisi kullanma düzeylerinin yüksek olması" (\%6,8), " Kendilerini daha yapılandırmacı görmeleri” (\%5,1), " ТРАВ öz yeterlik algılarının yüksek olması" (\%5,1), " Okul müdürlerinin iletişim becerisine ilişkin görüşlerinin olumlu yönde olması" (\%3,4), " Derste öğretim tekniklerini kullanma düzeylerinin yüksek olması" $(\% 3,4)$ ve " Örgütsel adalet alg1 düzeylerinin yüksek olması" $(\% 3,4)$ takip etmektedir.

Tablo 15'te "Diğer" $(\% 39,6)$ teması altında erkek sınıf öğretmenleri açısından anlamlı fark yaratan durumlar ise; "İşe tutkunluk", "Erkek çocukların oynadığı oyunlara hakim olma", "Psikolojik yıldırmaya maruz kalma”, "Serbest etkinlik dersini kullanma düzeylerinin yüksek olması”, “Akademik iyimserlik düzeylerinin yüksek olması”, “Umutsuzluk düzeylerinin yüksek olması”, “Öğretim materyali kullanma düzeylerinin yüksek olması”, “Bilgi teknolojilerine ilişkin olumsuz tutum içinde olma”, “Öğretmenlik mesleği genel yeterlik düzeylerinin yüksek olması”, “Mesleği ekonomik yönden yetersiz bulma”, "Eğitim algılarının yüksek olması", "Köyde barınma sorunu yaşama", "Çatışma tutum puanlarının yüksek olması”, "Kültürel dönüşüme ilgili olma", "Sosyalleşme algılarının yüksek olması", "İnsan ilişkileri sorunlarının performanslarına etki düzeyinin yüksek olması", Yaşam becerilerini kullanma düzeylerinin yüksek olması", "'Fen öğretimine ilişkin öz yeterlik algılarının yüksek olması", "'derste düşünme becerilerine yönelik etkinlik yapma düzeylerinin yüksek olması", "Örgütsel güven düzeylerinin yüksek olması", "Beden eğitimi ve oyun dersine yönelik öz yeterlik algı düzeylerinin yüksek olması" şeklinde yer almıştır.

\section{TARTIŞMA VE SONUÇ}

Birçok araştırmada değişken belirleme aşamasında ilk sıraya bazen "hiç düşünülmeden/üzerinde kafa yormadan/otomatik olarak" dahi yazllabilen "cinsiyet" değişkeninin anlamlı fark oluşturma durumlarını inceleme başlangıç noktası olan bu çalışmada sınıf öğretmenleri ile ilgili yapılan lisansüstü tezlerde "kadın" ve "erkek" sınıf öğretmenleri arasında anlamlı fark yaratan durumların nicel olarak ortaya konulması amaçlanmıştır. Bu araştırmada 2000-2020 yılları arasında YÖKTEZ tarama merkezinde sınıf öğretmenleri ile ilgili erişime açık olan 466 adet tezin yer aldığı ve bunlar arasından 141 tezde cinsiyet değişkeni açısından anlamlı farklılıkların bulunduğu tespit edilmiştir. Bu bağlamda araştırmaya 141 adet lisansüstü tez dahil edilmiştir. 
Sınıf öğretmenleri ile ilgili cinsiyet değişkenine bağlı olarak anlamlı farklılıkların bulunduğu 141 tezin 129'unun yüksek lisans tezi olduğu bulgusuna ulaşılmıştır. Cinsiyet değişkenine bağlı olarak anlamı farkların bulunduğu lisansüstü tezlerin ise en çok 2019 (\%18,4) yılında yapıldığı dikkat çekmiştir. En çok lisansüstü tezin de 2019 yılında yazılımış olmasının bu sonucu etkilemiş olabildiği söylenebilir.

İncelenen tezlerde tez yazarlarının çoğunun $(\% 54,6)$ erkek olduğu tespit edilmiştir. Aynı zamanda tez danışmanlarının da çoğunun $(\% 65,9)$ erkek olduğu bulgusuna ulaşılmıştır. Araştırma verilerini oluşturan tezlerde tez danışmanlarının çoğunluğunun (\%41,1) Dr. Öğr. Üyesi olduğu görülmektedir.

İncelenen tezlerde en çok nicel araştırma metodunun $(\% 85,1)$ kullanıldığı ve en çok ölçme aracı olarak ölçek $(\% 68,7)$ kullanıldığı sonucuna varılmıştır. İncelenen 141 tezin \%92,9'unun da tezlerde bulunan değişkenler arasında cinsiyetin birinci sırada yer aldığı dikkat çekmiştir. Bu durumda araştırmanın gerçekleşmesini destekleyen önemli bir sonuç olmuştur.

Araştırmaların en çok ilçe merkezlerinde $(\% 51,7)$ yapılması da çalışmanın bir diğer bulgusu olmuştur. Tezlerin örneklemini daha çok kadınların $(\% 65,9)$ oluşturduğu gözlenmiştir. Tezlerde cinsiyete bağlı olarak en çok bir adet $(\% 89,3)$ anlamlı farkın bulunduğu, tezlerde en çok kadınların lehine anlamlı farklılık yaratan durumların bulunduğu tespit edilmiştir.

Tezlerde ilk sıraya yazılan ve en çok tercih edilen değişken olan cinsiyet değişkeninin anlamlı fark yarattığı durumlar araştırmanın can alıcı noktalarıdır. Erkek sınıf öğretmenleri açısından en çok anlamlı fark yaratan durumların "Alan eğitimi dersleri öğretimine ilişkin yeterlik düzeylerinin yüksek olması" (\%12,0) ve "Öğretimsel liderlik düzeylerinin yüksek olması" (\%12,0) olduğu görülmektedir. Bu bulguları "İş doyum düzeylerinin yüksek olması" $(\% 8,6)$ takip etmiştir. Kadın sınıf öğretmenleri açısından en çok anlamlı fark yaratan durumların ise "Sınıf yönetimi becerilerinin yüksek olması" $(\% 8,5)$ olduğu saptanırken bu bulguyu sırasıyla " Üst düzey bilimsel süreç becerilerine ilişkin tutumlarının yüksek olması" $(\% 7,4)$ "Öz yeterlik algılarının yüksek olması" (\%5,3), ,"Empatik eğilimlerinin yüksek olması" (\%5,3) ve "Derslerde yaratıcı etkinlik uygulama düzeylerinin yüksek olması" $(\% 5,3)$ takip etmiştir.

\section{ÖNERILER}

Araştırma sonuçları çerçevesinde sınıf öğretmenleri ile ilgili daha çok doktora çalışmasının yapılması, araştırma kapsamının diğer branş öğretmenleri açısından da incelenerek genişletilmesi, cinsiyet değişkeni açısından anlamlı fark yaratan durumları derinlemesine incelemek adına nitel araştırma yönteminin kullanıldığı çalışmaların yapılması önerilebilir. Nitel ve karma araştırma yöntemleriyle elde edilen anlamlı farklılıkların nedenlerine ilişkin derinlemesine bir bakış açısı elde edilebilir. Ayrıca, daha çok ölçek kullanılması ve başarı 
testlerinin daha az kullanılması araştırmalarda öğrenci başarısının ihmal edildiğini göstermektedir. Bu yüzden, öğrenci başarısına yönelik araştırmaların yapılması önerilmektedir.

\section{KAYNAKLAR}

AA. (Anadolu Ajansı). (2019). Yükseköğretim istatistikleri açılandı. https://www.aa.com.tr/tr/egitim/yuksekogretim-istatistikleri-aciklandi/1468890. 02.06.2019 tarihinde erişildi.

Arıc1, H. (2001). Sosyal bilimler alanında bilim adam yetiştirme lisansüstü eğitim. Bilim Adamı Yetiştirme-Lisansüstü Eğitim, TÜBA Yayını, Bilimsel Toplantılar, 7, 53-64.

Aydın, R., Şahin, H., \& Topal, T. (2008). Türkiye'de ilköğretime sınıf öğretmeni yetiştirmede nitelik arayışları. Türkiye Sosyal Araştırmalar, 12(2), 119-142.

İnce, M. L., \& Korkusuz, F. (2006). Lisansüstü eğitim hedeflerini geliştirmede öğrenci öğretim üyesi etkileşimi: bir disiplinin farkl üniversitelerde ve farkh disiplinlerin bir üniversitedeki durumu. TÜBITTAK Sosyal ve Beşeri Bilimler Araştırma Grubu, Proje No: 104K093.

Gürkan, T. (1993). Illkokul Öğretmenlerinin öğretmenlik tutumlarn ile benlik kavramları arasındaki ilişki. Ankara: Sevinç Matbaası.

Güven, İ., \& Tunç, B. (2007). Lisansüstü öğretim öğrencilerinin akademik sorunları: Ankara Üniversitesi eğitim bilimleri enstitüsü örneği. Eğitim Bilimleri, 173, 157-171.

Karaman, S., \& Bakırcı, F. (2010). Türkiye' de lisansüstü eğitim: Sorunlar ve çözüm önerileri. Sosyal Bilimler Araştırmaları Dergisi, 2, 94-114.

Karasar, N. (2005). Bilimsel araştırma yöntemleri (15. Baskı). Ankara: Nobel Yayın Dağıtım.

Kavcar, C. (1987). Yüksek öğretmen okulunun öğretmen yetiştirmedeki yeri. Öğretmen Yetiştiren Yüksek Öğretim Kurumlarmın Dünü-Bugünü-Geleceği Sempozyumu, Gazi Üniversitesi Ankara.

Köseoğlu, K. (1994). İlköğretime öğretmen yetiştiren kurumlarda öğretim eleman yeterliklerinin değerlendirilmesi. Yayımlanmamış Yüksek Lisans Tezi, Ankara Üniversitesi Sosyal Bilimler Enstitüsü, Ankara.

$\begin{array}{lllll}\text { MEB. } & \text { (2019). Milli } & \text { eğitim } & \text { istatistikleri. }\end{array}$ http://sgb.meb.gov.tr/meb_iys_dosyalar/2019_09/30102730_meb_istatistikleri_orgun_e gitim_2018_2019.pdf 25.04.2020 tarihinde erişildi.

Resmi Gazete. (2018). Yükseköğretim kanunu ile bazı kanun ve kanun hükmünde kararnamelerde değisşiklik yapılmasına dair kanun. https://www.resmigazete.gov.tr/eskiler/2018/05/20180518-1.htm. 30.03.2020 tarihinde erişildi. 
Senemoğlu, N. (1992). İngiltere'de ilköğretime öğretmen yetiştirme ve Türkiye ile karşılaştırılması: Türkiye'de ilköğretime öğretmen yetiştirmenin geliştirilmesi için bazı öneriler. Hacettepe Üniversitesi Ĕ̆itim Fakültesi Dergisi, 8, 143-156.

Sevinç, B. (2001). Türkiye' de lisansüstü eğitim uygulamaları, sorunlar ve uygulamalar. DEÜ Eğitim Fakültesi Dergisi, 34(1),25-40.

YÖKTEZ. (2019). Tez tarama. https://tez.yok.gov.tr/. (31.07.2019'da erişildi.).

Etik Kurul Kararı: Bu araştırma verilerinin toplanmasında canlılara yönelik bir işlem olmadığından etik kurul kararı zorunluluğu taşımamaktadır. 